Homelessness and the Ethics of Information Access

\author{
Corina Bardoff ${ }^{1}$ \\ MSLIS, Pratt Institute School of Information and Library Science \\ Adult Librarian, Brooklyn Public Library, Brooklyn, New York, USA
}

${ }^{1}$ Direct correspondence to: Corina Bardoff, Marcy Library, 617 DeKalb Ave, Brooklyn, NY 11216. E-mail: CBardoff@bklynlibrary.org. Thanks to Dr. Debbie Rabina, Associate Professor at Pratt SILS. 


\section{Homelessness and the Ethics of Information Access}

Many public libraries have rules against strong body odor, bringing large amounts of luggage into the library, sleeping, and bathing in restrooms. These rules disproportionately affect library patrons who are experiencing homelessness. This paper reviews recent literature that considers legal and social justice perspectives on homelessness and libraries, as well as the policies of four urban public library systems. Though these rules may be legal and are widely used, people without homes have no other access to information. This paper concludes that blocking their access conflicts with the mission of public libraries to provide information to all.

\section{KEYWORDS homelessness, ethics, public libraries, information access}

\section{Introduction}

Public libraries' treatment of patrons who are experiencing homelessness is a prominent subject in library and information science (LIS) and the news more generally. Some common topics include whether it is legal to expel someone from a public library because of their odor, appropriate and inappropriate uses of library facilities, social workers based in libraries (as in the San Francisco Public Library), and partnerships between public libraries and homeless outreach organizations to better serve patrons experiencing homelessness. This paper addresses the question of access to the library by people experiencing homelessness from an intellectual freedom/equitable access perspective. Rather than providing legal advice or policy prescriptions (of which there are many available), I look at this from an ethical perspective and explore whether it is ever justified to block someone's access to information, and if so, in what circumstances. Is it ethical to block a person's access to a public library because they make other patrons uncomfortable - whether because of odor, appearance, or behavior? These questions could be asked of any library patron, but because patrons experiencing homelessness are perhaps the most discussed in terms of barring their access, I have focused on literature about them.

\section{Research Question and Method}


This paper sought answers to the following research question: Is it ethical to block a person's access to a public library because they make other patrons uncomfortable - whether because of odor, appearance, or behavior? I answered this question by reviewing recent literature that discusses access to public libraries by people experiencing homelessness.

\section{Literature Review}

This paper examines recent literature about access to public libraries, focusing in particular on writing about people experiencing homelessness. First, I will discuss literature about "problem patrons" and behavior policies in public libraries. Then, I will cover legal perspectives, reviewing LIS interpretations of case law pertaining to patron behavior in libraries. In the third section of the literature review, I will discuss the social responsibilities of libraries and criticisms of the policies in the first section. Finally, I look outside of the LIS field to urban geographer Don Mitchell and his consideration of anti-homeless laws in American cities.

\section{Appropriate vs. Inappropriate Uses of the Library / "Problem Patrons"}

I will begin by examining discussions of library security and "problem patrons," paying close attention to assumptions about appropriate and inappropriate uses of a library. I will also review several policies of large urban library systems.

Published by the American Library Association in 2012, The Black Belt Librarian: RealWorld Safety and Security was written by Warren Graham, a retired library security manager with more than two decades of experience. Black Belt Librarian is a guide to creating security procedures and policies for patrons in public libraries. Graham advocates simply stated policies, 
well-trained staff (security and librarians, alike), and fair enforcement of rules for all patrons. ${ }^{2}$ Embedded in Graham's advice are assumptions about what purpose the library serves and who the library is for: "Intermingled with the majority of patrons, who were all there for the right reasons and enjoying the facility, were a mix of behavior problems that ran the gamut from the innocuous to the insane" (emphasis mine). ${ }^{3}$ The phrase "the majority of patrons" is syntactically parallel to "behavior problems," reducing a minority of patrons to their behavior alone. The library, it is implied throughout the text, is for research, reading, and for checking out materials those are the "right reasons" to use the library. Wrong reasons, or inappropriate uses of the library according to Graham, include bathing in the restrooms, stacking metal washers, and staring at the ceiling. Graham suggests that by allowing these "behavior problems" to use the library, libraries are denying access to the "regular, true library user." ${ }^{, 4}$ was particularly interested in Graham's suggested prohibition of "loitering" in the library. "People in the library should be using the library," he says. "If you let people just come in and hang out for whatever reason, it lends itself to behavior problems." 5 This conception of just "hanging out" affects people experiencing homelessness, as many come to the library seeking shelter from weather when everywhere else they might go charges money to be there.

In my review of the literature, I noticed a trend of articles that offered suggestions for dealing with "problem patrons." Most of this writing came from the 1980s and early 1990s.

2. Warren Graham, The Black Belt Librarian: Real-World Safety and Security, (Chicago: American Library Association, 2013).

3. Ibid., vxi.

4. Ibid.

5. Ibid., 12. 
Much of the more recent literature that I read critiqued this approach. Because it is a bit older, I include only one example of this "problem patron" literature for context.

Patron Behavior In Libraries, published by the American Library Association in 1996, addresses a wide range of patron behaviors. The chapter by Bruce A. Shuman, "Down and Out in the Reading Room: The Homeless in the Public Library," discusses behaviors associated with patrons experiencing homelessness, and is exemplary of "problem patron" literature. Shuman classifies "problem patrons" into three categories and lists the "representative behaviors" of each category: “Class I Dangerous (very serious)," “Class II Who Knows? (serious but...),” and "Class III Nuisances (annoying but harmless)."6 The behaviors listed in Class I are undeniably very serious problems: child molesting, committing arson, and felonious, for example. In Class II, however, "homeless" is listed as a behavior. Other behaviors in Class II that could be associated with homelessness are "acting weird" and "loitering." In Class III, "begging," “malodorous," "lonely," and "sleeping" could apply to anyone, but are all behaviors associated with people experiencing homelessness. Shuman balances arguments in favor of barriers to "the homeless" and arguments against those behaviors. Arguments for barriers include wanting to maintain a pleasant environment in the library; not using the library for "library purposes" is grounds for expulsion; and library staff, who cannot expel patrons who smell terrible and/or who are experiencing homelessness have to deal with the smell and may be stressed out by complaints from patrons who have homes and presumably do not smell bad. ${ }^{7}$ Two assumptions are present in these arguments: 1) that there are appropriate or correct ways to use public

6. Bruce A. Shuman, "Down and Out in the Reading Room: The Homeless in the Public Library," in Patron Behavior In Libraries: A Handbook of Positive Approaches To Negative Situations, eds. Beth McNeil and Denise J. Johnson, (Chicago: American Library Association, 1996), 9.

7. Ibid., 13. 
libraries and 2) that people experiencing homelessness are necessarily nuisances to people who have homes. Shuman lists arguments against barriers: people without homes have rights like anyone else, and "it may be illegal to treat homeless persons differently." 8

To see this balancing act in practice, I looked at the current policy statements at four large, metropolitan public libraries. All the policies are available on the libraries' websites. It is out of the scope of this paper to do a comprehensive survey of public library policies in the United States, but I have tried to be geographically diverse at least: I looked at policies from Brooklyn, Dallas, St. Louis, and San Francisco.

Brooklyn Public Library's policy begins by stating that the rules it outlines are intended to "protect the rights and safety of library users" and staff. Patrons who violate the rules "may be subject to suspension of their Library privileges," be excluded from the Library and/or face legal action. Many of these regulations are completely uncontroversial, such as the prohibition of illegal behavior or destroying library property. The policy also includes rules against “inappropriate behavior" such as “(d)istrubing others because of offensive body odor," having a bare chest or bare feet, and using restrooms for "bathing, shaving, washing hair, or changing clothes." 9 The policy also prohibits bringing shopping carts into the library, and the library "reserves the right to limit the size and number of items brought into the Library." 10

The Dallas Public Library's policy was written by the city government and applies to recreation centers as well as libraries. The policy begins by stating that the goal is to create an

\section{Ibid., 13-14.}

9. Brooklyn Public Library, "Public Behavior In the Library Policy," Brooklyn Public Library, June 27, 2013, http://www.bklynlibrary.org/policy/public-behavior.

10. Ibid. 
"open and inviting atmosphere" in libraries and recreation centers, and the Code of Conduct was created to ensure this atmosphere is maintained. Penalties for violating the Code of Conduct include expulsion from the facility and criminal prosecution. ${ }^{11}$ The Code states "City staff will enforce these guidelines in a consistent and impartial manner." 12 The Code has two sections that list behaviors prohibited by the Texas Penal Code and the Dallas City Code. These would all be difficult to argue with, such as prohibitions against assault and littering. Below these is another section: "The following behaviors are prohibited if in the clear judgment of city staff, on a caseby-case basis, they disrupt the environment for other users of the facilities..." ${ }^{13}$ These behaviors include "emitting odors (including bodily odors or perfumes) [that] interfere with the use of services by other users or the work of staff," panhandling, "entering into City buildings with large framed backpacks, bedrolls, blanket rolls, or more than three grocery-sized paper or plastic bags or parcels," and "defects of bodily hygiene."14 The Code of Conduct also prohibits the use of libraries and recreation centers "for other than their intended purposes." The Code does not describe the intended purposes of libraries, but does list examples of inappropriate uses, such as loitering, bathing, and washing clothes. ${ }^{15}$

The St. Louis Public Library's policy is titled "Appropriate use of the Library." The policy begins by stating the mission of the library and the state law that gives the library the

11. City of Dallas, "Libraries and Recreation Centers Code of Conduct, Dallas Public Library, accessed April 9, 2015, http://dallaslibrary2.org/about/policy-codeOfConduct.php.

12. Ibid.

13. Ibid.

14. Ibid.

15. Ibid. 
authority to create it's own rules and regulations. The introduction of the policy states: "The Board acknowledges that there are several appropriate uses for library facilities and that behavior suitable for some occasions and spaces within the Library is not appropriate for others."16 The first section concerns state and local ordinances, and are standard prohibitions against illegal activities. The second section "Prohibitions By Library Policy," requires library patrons to "be engaged in activities associated with the use of a public library while in the building. Patrons not engaged in reading, studying, or using library materials shall be required to leave the building." 17 The policy also prohibits "inappropriate behavior" such as sleeping, bathing and doing laundry, requires shoes and shirts, prohibits patrons from bringing in items that do not fit underneath a library chair, bans begging, and bans "bodily hygiene ... offensive so as to constitute a nuisance to other patrons." 18 After the first offense, patrons must leave the library and stay away for one day. After the second offense, patrons are evicted for one week. After repeat offenses, library privileges can be revoked for six months. ${ }^{19}$

The San Francisco Public Library's Patron Code of Conduct begins by stating that the library "welcomes all residents and visitors of the City" to the library and "seeks to provide its patrons with a safe and pleasant library experience in an atmosphere conducive to study, reading,

16. St. Louis Public Library, "Appropriate Use of the Library," St. Louis Public Library. September 10, 2007, http://stlouispubliclibrary.net/slpl/library/Article240096442.asp.

17. Ibid.

18. Ibid.

19. Ibid. 
learning and appropriate use of materials and services." 20 The code of conduct is divided into three sections: Level 1 - "Severe Violations," Level 2 - Moderate Violations, and Level 3 "Minor Variations." As with the library policies described above, the first two levels list extreme violations such as assault (level 1), violating someone's privacy in the rest room (level 2), and vandalism (level 2). Level 1 violations result in one-year suspensions for the first offense, twoyear suspensions for the second, and three-year suspensions for the third. Level 2 violations result in suspensions of 3 months for the first offense, 6 months for the second, and 1 year for the third. $^{21}$ The rules around level 3 violations are those that would most affect people experiencing homelessness: rules against carts and luggage, a rule against "Emitting strong, pervasive odors," and rules against using the library facilities "for other than their intended purpose." The San Francisco Public Library's facilities are not intended for "loitering, bathing... shampooing, shaving, personal grooming, changing clothes, washing clothes or utensils." 22 The policy cites California Penal Code $\S 370$ after rules against strong odors and using library facilities inappropriately. For level 3 offenses, patrons receive a warning, and will be asked to leave if they do not correct their behavior. After a second offense, patrons are suspended for one day. After a third offense, patrons are suspended for a week. ${ }^{23}$

All four of the public libraries in this small survey have rules against body odor and bringing in large items like luggage and shopping carts. The Dallas Public Library and the San

20. San Francisco Public Library Commission, "Patron Conduct Policy - Patron Code of Conduct," San Francisco Public Library, September 18, 2014, http://sfpl.org/pdf/about/commission/policy201.pdf.

21. Ibid.

22. Ibid.

23. Ibid. 
Francisco Public Library prohibit loitering. In three out of four of the public library policies examined above, the phrase "inappropriate behavior" was used. The exception, Dallas, dictates that the library be used for its "intended purposes." St. Louis Public Library's policy emphasizes the most what "appropriate" use of the library is, going so far as to expel anyone not reading, studying, or using library materials.

\section{Legal Perspectives}

In this section, I review legal cases that tested library policies about patron behavior, and literature about the implications for libraries. There has been much written about the legality of public library policies, and I have selected two examples.

The first is a piece from Public Libraries in 2006: "Barefoot in Columbus: The Legacy of Kreimer and the Legality of Public Library Access Policies Concerning Appearance and Hygiene" by James Kelly. Kelly's piece is useful because it describes three court cases about patron hygiene. The first case discussed is Kreimer v. Bureau of Police for the Town of Morristown: in 1992, Richard Kreimer, a man who was homeless, sued the Morristown (New Jersey) public library and police department for expelling him from the library, at least five times, because of his odor and appearance. The disputed polices in this case were:

Patrons shall not be permitted to enter the building without a shirt or other covering of their upper bodies or without shoes or other footwear.

Patrons whose bodily hygiene is so offensive as to constitute a nuisance to other persons shall be required to leave the building. ${ }^{24}$

24. Kreimer v. Bureau of Police for Town of Morristown, 765 F.Supp. 184, quoted in James Kelly, "Barefoot in Columbus: The Legacy of Kreimer and the Legality of Public Library Access Policies Concerning Appearance and Hygiene," Public Libraries 45, no. 3 (2006): 43. 
District Judge Sarokin found in favor of Kreimer, writing in his opinion of the "danger of excluding anyone from a public building because their appearance or hygiene is obnoxious to others." ${ }^{, 25}$ Judge Sarokin said that the library had violated Kreimer's First Amendment rights, which includes the right to receive information. The judge considered public libraries to be a public forum, and the problem with the library's restrictive policy was that it does not serve the stated purpose of the library, which is to allow all people to use the library's services and sources to the fullest possible extent. The Third Circuit found that the library's rule about hygiene was valid because "it served the government interest of having other patrons not interfered with and maintaining the library in a clean and attractive condition." ${ }^{26}$ Kelly notes that the Kreimer case raised more questions than it answered regarding hygiene policies.

Next, Kelly describes Armstrong v. District of Columbia Public Library, a case from 2001, in which a person who was experiencing homelessness was ejected from a public library because of his body odor and appearance. The district court found that the library's policy was too vague and "overbroad." ${ }^{27}$ The decision confirmed that libraries can expel patrons based on their appearance or hygiene, but that "the criteria should fit within a legal standard, not the subjective opinions of the staff., 28

The final case discussed by Kelly, Neinast v. Board of Trustees of Columbus Metropolitan Library, did not involve a person who was experiencing homelessness, but

\section{Ibid.}

26. Kelly, James. "Barefoot in Columbus: The Legacy of Kreimer and the Legality of Public Library Access Policies Concerning Appearance and Hygiene," Public Libraries 45, no. 3 (2006): 44.

27. Ibid., 45.

28. Ibid. 
nonetheless sheds light on the topic. Robert Neinast, a member of the Dirty Sole Society, regularly goes without shoes. He was asked to leave the Columbus (Ohio) Metropolitan Library because of their policy against bare feet, and in 2001 Neinast sued the library board of trustees, claiming that a public library is a public forum: he claimed his First Amendment rights to access information from the public library and to free speech (his refusal to wear shoes) were violated. ${ }^{29}$ The Sixth Circuit found that the First Amendment does protect the right to receive information, but that the library is a limited public forum and does not have to provide unlimited access: the library has to allow the public to exercise only those rights that are consistent with the nature of the library. The court also found that going barefoot is not protected speech because it does not convey a particularized political, ideological, or religious message, and because it was unlikely that people in the library or elsewhere would understand the intended message. ${ }^{30}$ Neinast also sued on the basis of $14^{\text {th }}$ Amendment discrimination, saying that he was denied equal protection under the law because the library's shoe regulation discriminates against a group of people those who go without shoes. The court found that those who go without shoes by choice are not a suspect class - "a class for which discrimination is unlikely to serve a valid purpose," such as race or religion. ${ }^{31}$ Kelly does not consider whether people experiencing homelessness are a suspect class.

In his conclusion, Kelly focuses on the fact that public libraries are a limited public forum, meaning that libraries can put restrictions in place that limit use of the library to "its

29. Ibid., 46.

30. Ibid., 46-47.

31. Ibid., 47. 
intended purposes." ${ }^{32}$ Kelly does not think that people using the library as a "daytime refuge from the elements and the streets" is an intended purpose. He also writes that expelling someone from a public library because of appearance or hygiene is legal as long as restrictions are "clear, reasonable, and objective."33

An earlier paper, "Legal Issues Regarding Library Patrons” by Katherine Malmquist, from Patron Behavior In Libraries, also considers whether a public library is a public forum. Malmquist looks at case law, and determines that a public library is not a traditional public forum, but is a designated public forum, which means they "need not be open to all First Amendment activities." ${ }^{34}$ Rules should be specific, fair, based on the purpose of the library, and can prohibit behavior that would be "disruptive to or interfere with the use of the library by other patrons.",35

\section{Social Justice}

Through the articles in this section, I will discuss the social responsibilities of libraries and criticisms of the policies described above. Barring someone's access may be legal, but is it just?

This paper was inspired by a presentation I attended at the ALA Annual Conference in Las Vegas in June 2014. Elizabeth Skinner, Associate Director and LSTA Project Coordinator of

32. Ibid., 48.

33. Ibid., 48.

34. Malmquist, Katherine, "Legal Issues Regarding Library Patrons," in Patron Behavior In Libraries: A Handbook of Positive Approaches To Negative Situations, eds. Beth McNeil and Denise J. Johnson, (Chicago: American Library Association, 1996), 97.

35. Ibid., 98. 
the Forsyth County Public Library (Winston-Salem, NC) gave a talk titled "People Experiencing Homelessness: How Libraries Can Be Community Collaborators \& Catalysts For Positive Action." In this paper I have referred to people who are experiencing homelessness rather than "homeless people" or "the homeless" because of Skinner's talk; she said, "Homelessness is a state, not a trait." 36 The Forsyth County Public Library has done much both to serve the people in their community who are experiencing homelessness and to educate their community and staff about the experience of homelessness. The library staff participated in poverty simulations as part of sensitivity training. Unable to require sensitivity training of their entire community, the library used a "one book, one community" program to educate the public and inspire discussion and empathy. The Forsyth County Public Library has been innovative in their services to people in their community who are experiencing homelessness by collaborating with homelessness service providers and offering programs and services tailored to people experiencing homelessness: classes on computer skills, life skills, medicine and health, and entertainment the library asked this population what they wanted. ${ }^{37}$ Not all libraries will be able to do exactly what Forsyth County Public Library has done, but it is an inspiring model for those who want to better serve their entire community.

In 2012, the American Library Association released a policy statement on library services to the poor: "Extending Our Reach: Reducing Homelessness Through Library Engagement." The statement is based on the goal that libraries should provide and promote equal access to information to all people. ALA acknowledges the barriers created by poverty and by

36. Elizabeth Skinner, "People Experiencing Homelessness: How Libraries Can Be Community Collaborators \& Catalysts for Positive Action" (Conference presentation, American Library Association Annual Conference, 2014).

37. Ibid. 
homelessness, and advocates a proactive role for libraries in addressing poverty. ${ }^{38}$ The statement lists 14 ways libraries can work to achieve this objective, including removal of barriers like late fees, collection development that includes materials that address poverty and homelessness, and some of the programs implemented by the Forsyth County Public Library, such as "promoting increased public awareness" and "training to sensitize staff. ${ }^{39}$

In "The Dilemma of Urban Library Service for the Homeless," Lan Shen describes three different types of support to patrons who are experiencing homelessness in public libraries: “cooperative service with local government agencies and local communities," offering help outside the public library, and providing service to patrons experiencing homelessness within the library. ${ }^{40}$ Shen calls partnerships a "win-win" scenario, as the library receives financial support from the local government and the local government can use the library as a vehicle to provide services. Providing services in homeless shelters, welfare hotels, and day-care shelters can bring library services to those who may not visit the library at all. Offsite services can also be a compromise with those who complain about the presence of people who appear to be experiencing homelessness within the library, for example complaints about body odor or someone carrying an abundance of luggage. The third category, service within libraries, is meant to signify services specifically for patrons experiencing homelessness, such as referrals to and

38. American Library Association, "Extending Our Reach: Reducing Homelessness Through Library Engagement," American Library Association, October 8, 2012, http://www.ala.org/offices/extending-our-reach-reducing-homelessness-through-libraryengagement-7.

39. Ibid.

40. Lan Shen, "The Dilemma of Urban Library Service for the Homeless," Current Studies in Librarianship 26, no. 1/2 (2002). 
information about free services, and specialized literacy programs. ${ }^{41}$ Shen's peculiar sentence at the end of this section - "Some libraries, like the San Francisco Public Library, allow the homeless to check out library materials" ${ }^{\prime 2}$ - indicates that many libraries do not do this, because they require a permanent address to sign up for a library card. Shen outlines typical restrictions that affect patrons who are experiencing homelessness: bans on offensive odor, prohibitions of bringing "strange" things into the library, and rules against "improper" restroom use, for example, using library restrooms to bathe, shave, or change clothes. ${ }^{43}$ Shen cautions that these restrictions turn librarians into virtual police, and urges compassion. Those experiencing homelessness experience a "poverty of rights" that comes along with economic poverty. ${ }^{44}$ Without homes, people lack privacy and easy access to information. In agreement with ALA's policy statement, Shen suggests that librarians can be advocates for their patrons who are experiencing homelessness. ${ }^{45}$

In 2005, Sanford Berman delivered ALA's $6^{\text {th }}$ Annual Jean E. Coleman Library Outreach Lecture at the ALA Annual Conference in Chicago: "Classism in the Stacks: Libraries and Poverty." Berman founded the task Force on Hunger, Homelessness, and Poverty of ALA's Social Responsibilities Round Table, and co-authored the Poor People's Policy (PPP). "Extending Our Reach: Reducing Homelessness Through Library Engagement" is the updated version of this policy. In his lecture, Berman laments that no libraries had formally adopted the

41. Ibid.

42. Ibid., 79.

43. Ibid.

44. Ibid., 81.

45. Ibid. 
PPP as their own policy, though hundreds had adopted the Library Bill of Rights. ${ }^{46}$ He has two explanations for this. The first is that librarians may think: "the library's for everybody. Why focus on one particular group or demographic?" The second explanation is that the culture of the United States is that of a plutocracy, in which wealth determines social worth. The myth of the American dream and Calvinist predestination assert that if someone is not prosperous, it is their own fault. ${ }^{47}$ Berman decries examples of discrimination against people who are poor in libraries, a few of which I will include:

- Kansas City Public Library security guards handed out "customer behavior expectations" brochures at the entrance.

- A law in San Luis Obispo, CA banned "offensive body odor" and sleeping in the public library

- The City Council in Houston, TX passed library regulations that prohibited "sleeping on tables, eating packaged food, using rest rooms for bathing, offensive bodily hygiene that constitutes a nuisance to others... and large amounts of personal possessions."

Berman wonders: “why aren’t poverty, homelessness, and hunger the primary object of our wrath, our discomfort?" ${ }^{48}$ He offers many recommendations for libraries to address homelessness and poverty in their communities, and to serve patrons who are experiencing homelessness, including: adopting and implementing the Poor People's Policy, supporting antipoverty legislation, collaborating with community organizations that support people experiencing

46. Sanford Berman, "Classism In the Stacks: Libraries and Poverty," Journal of Information Ethics 16, no. 1 (2007).

47. Ibid.

48. Ibid. 
homelessness, producing bibliographies of and stocking resources useful to poor people, collecting "authentic" materials for the collection that can help "sensitize the 'comfortable' to

poverty as a critical issue," and reexamining library policies that adversely affect poor people. ${ }^{49}$

\section{Equitable Access to Information}

The Right to the City: Social Justice and the Fight for Public Space (2003) by geographer Don Mitchell, does not discuss libraries at all, but it is a useful framework to consider libraries as public spaces and public resources (and public forums). I have focused on Mitchell's two chapters about anti-homeless laws and zoning: Chapter 5 "The Annihilation of Space by Law: Anti-Homeless Laws and the Shrinking Landscape of Rights" and Chapter 6 "No Right to the City: Anti-Homeless Campaigns, Public Space Zoning, and the Problem of Necessity."

Mitchell argues that limitations on what can be done in public spaces limit what people experiencing homelessness can do at all because they have no private space of their own. This is in line with Shen's concept of a poverty of rights. Mitchell describes so-called "quality of life" laws that aim to better the quality of life for most of their citizens (and to attract business) at the expense of people who are poor and experiencing homelessness. Here are some illustrative examples from Mitchell:

- "zero tolerance" policies in San Francisco for violations of laws against "camping in public, loitering, urinating and defecating in public, and drinking in public places"

- laws against sleeping in public places in many U.S. cities

- laws against cutting across or loitering in parking lots in Atlanta and Jacksonville

- laws against or restrictions on begging

49. Ibid. 
- laws against sitting on sidewalks between 7 A.M. and 9 P.M. ${ }^{50}$

Mitchell's book was published in 2003, but while some specific examples may be out of date, the bigger picture remains relevant. Laws against sleeping in public and sitting on the sidewalk are particularly egregious, but all these laws are appalling for outlawing basic human necessities. Mitchell puts it very well: "Survival itself is criminalized." ${ }^{51}$ Space matters little if one is rich (or at least not poor), because there is no worry about places to go to the bathroom, places to sleep, places to sit, or places to simply be. If I need to go to the bathroom while out, and I cannot find a public restroom, I can simply buy something at a restaurant, and use their toilet. These quality of life laws redefine what is acceptable behavior in public spaces, and public spaces, Mitchell points out, are where people experiencing homelessness must live: "The current restrictions on homeless people's behavior in public space are clearly an effort to regulate space so as to eliminate homeless people, not homelessness." ${ }^{, 52}$ Because they are without homes, people experiencing homelessness can only have "the possibility of sovereignty over their own actions $[\ldots]$ on common or public property."

All these regulations, according to Mitchell, imply that poor people, people so poor they have no home, "have no right to the city." ${ }^{54}$ What about a right to the public library or to information? The library policies discussed above, by banning strong odors and large bags, for example, weigh the right to be comfortable above the right to use the library by everyone. The

50. Don Mitchell, The Right to the City: Social Justice and the Fight For Public Space (New York: Guilford Press, 2003), 162-163.

51. Ibid., 163.

52. Ibid., 167.

53. Ibid., 170.

54. Ibid., 181 
anti-homeless laws Mitchell describes are part of what he calls the "ideology of comfort;" laws against panhandling, for example, criminalize "not assault or threat-making but rather making someone feel uncomfortable... Discomfort, however, is a far cry from 'wrong' or 'dangerous.","55 Strong body odor naturally makes us uncomfortable, but our right against discomfort should not be given more weight than a person right to use the library.

Elizabeth Skinner cautioned against thinking of homelessness as a personal trait and considering "the homeless" to be a homogenous group. Still, homelessness is a class status, and it is illegal to criminalize someone for their class status or condition. Anti-homeless laws get around this by criminalizing behavior. Mitchell's example is anti-camping laws, which apply to

everyone, but only affect people with no place to sleep other than in public. ${ }^{56}$ The prohibition of certain activities in some spaces is a "total prohibition for some people" (emphasis is Mitchell's). ${ }^{57}$ These laws do criminalize poverty.

People who are experiencing homelessness have few or no options to access information other than public libraries, and thus the interest of library patrons in studying without smelling foul odors, for example, does not outweigh a person's right to information or their right to simply be in a public space.

\section{Findings and Conclusions}

I set out to answer if it is ever ethical to block a person's access to a public library because they make other patrons uncomfortable. I found that it is widely considered legal and

55. Ibid., 181.

56. Ibid., 202.

57. Ibid., 172. 
justifiable to expel someone from a public library for behavior associated with homelessness, such as carrying luggage, having a strong body odor, and bathing in library restrooms. The patron behavior policies of the four urban public libraries that I reviewed all have rules that affect people experiencing homelessness, and two publications by ALA recommend such rules. These restrictions may be legal, and serving as a homeless shelter may not be the mission of a public library, but public libraries have an obligation to serve everyone in their community. If the mission of the library is to meet the information needs of their community, the library's policies should be considered in that light. The literature in my "social justice" section criticizes these restrictive policies, and advocates for libraries to do more to help their poorest patrons.

None of the literature I reviewed considered the right to information. People (with or without homes) use public libraries to find jobs, to find services and housing, to stay in touch with friends and family, to read the news, and to read for pleasure. But even if someone is in the library not seeking information, and is instead simply seeking a place to sit out of the sun or cold (or because it is illegal for them to sit anywhere else), expelling that person from the library is still a violation their right to information. Just as Mitchell points out that making it illegal to sleep in public makes it illegal for those without homes to sleep at all, ejecting someone from a library because they smell blocks their access to information; what other source of information do they have? 


\section{Bibliography}

American Library Association. "Extending Our Reach: Reducing Homelessness Through Library Engagement." American Library Association. October 8, 2012. http://www.ala.org/offices/extending-our-reach-reducing-homelessness-through-libraryengagement-7.

Berman, Sanford. "Classism In the Stacks: Libraries and Poverty." Journal of Information Ethics 16, no. 1 (2007): 103-110.

Brooklyn Public Library. "Public Behavior In the Library Policy." Brooklyn Public Library. June 27, 2013. http://www.bklynlibrary.org/policy/public-behavior.

City of Dallas. "Libraries and recreation centers code of conduct." Dallas Public Library. Accessed April 9, 2015. http://dallaslibrary2.org/about/policy-codeOfConduct.php.

Graham, Warren. The Black Belt Librarian: Real-World Safety and Security. Chicago: American Library Association, 2012.

Kelly, James. "Barefoot in Columbus: The Legacy of Kreimer and the Legality of Public Library Access Policies Concerning Appearance and Hygiene." Public Libraries 45, no. 3 (2006): 42-49.

Malmquist, Katherine. "Legal Issues Regarding Library Patrons." In Patron Behavior In Libraries: A Handbook of Positive Approaches To Negative Situations, edited by Beth McNeil and Denise J. Johnson, 95-105. Chicago: American Library Association, 1996.

Mitchell, Don. The Right to the City: Social Justice and the Fight For Public Space. New York: Guilford Press, 2003.

San Francisco Public Library Commission. "Patron Conduct Policy - Patron Code of Conduct." San Francisco Public Library. September 18, 2014. http://sfpl.org/pdf/about/commission/policy201.pdf.

Shen, Lan. "The Dilemma of Urban Library Service for the Homeless." Current Studies in Librarianship 26, no. 1/2 (2002): 77-83.

Shuman, Bruce A. "Down and Out in the Reading Room: The Homeless in the Public Library." In Patron Behavior In Libraries: A Handbook of Positive Approaches To Negative Situations, edited by Beth McNeil and Denise J. Johnson, 3-17. Chicago: American Library Association, 1996.

Skinner, Elizabeth. "People Experiencing Homelessness: How Libraries Can Be Community Collaborators \& Catalysts for Positive Action." Conference presentation, American Library Association Annual Conference, 2014. 
Homelessness and the Ethics of Information Access 22

St. Louis Public Library. "Appropriate Use of the Library." St. Louis Public Library. September 10, 2007. http://stlouispubliclibrary.net/slp1/library/Article240096442.asp. 